\title{
Native-valve Enterococcus hirae endocarditis: a case report and review of the literature
}

\author{
Mary E. Pinkes ${ }^{1 *} \mathbb{D}$, Catherine White ${ }^{2}$ and Cynthia S. Wong ${ }^{3}$
}

\begin{abstract}
Background: Enterococcus hirae is rarely identified in humans and may be a commensal pathogen in psittacine birds. We present the fifth known case of $E$. hirae endocarditis.

Case presentation: A 64-year-old Caucasian female presented with fever, hypotension, atrial fibrillation with rapid ventricular response, and a two-week history of lightheadedness. Her previous medical history included COPD, recurrent DVT, atrial fibrillation (on warfarin), hypertension, hypothyroidism, and Hodgkin's lymphoma. Physical exam was notable for expiratory wheezes and a 2/6 systolic ejection murmur at the right sternal border. 2D echocardiogram revealed severe aortic stenosis. The patient underwent right and left heart catheterization, where she was found to have severe aortic stenosis and mild pulmonary hypertension. She subsequently underwent minimally invasive aortic valve replacement with a bovine pericardial valve, bilateral atrial cryoablation, and clipping of the left atrial appendage. Her aortic valve was found to have a bicuspid, thickened appearance with calcifications, multiple small vegetations, and a root abscess beneath the right coronary cusp. With a new suspicion of infective endocarditis, the patient was placed on broad-spectrum IV antibiotics. Intra-operative blood cultures were negative. A tissue culture from the aortic valve vegetations identified Enterococcus hirae susceptible to ampicillin through MALDI-TOF. Antibiotic treatment was then switched to IV ampicillin and ceftriaxone; she declined aminoglycoside treatment due to toxicity concerns. The patient had an uncomplicated postoperative course and was discharged with 6 weeks of antibiotics. To date, she continues to be followed with no signs of relapsing disease.
\end{abstract}

Conclusions: To our knowledge, this case constitutes the fifth known case of E. hirae endocarditis, and the second case to have been identified with MALDI-TOF and treated with ampicillin and ceftriaxone. This case reinforces the efficacy of ampicillin and ceftriaxone for the treatment of $E$. hirae endocarditis.

Keywords: Enterococcus hirae, Enterococci, Endocarditis, Aortic valve endocarditis

\section{Background}

Enterococci are Gram-positive, facultative anaerobes frequently found in the intestinal flora of humans and animals [1]. In recent years, they have attracted notice as an increasingly common source of hospital-acquired infections, particularly with concerns about antibiotic resistance [2]. Enterococcus faecalis and E. faecium are the most commonly identified species, classically accounting for roughly 80 and $10 \%$, respectively, of all enterococcal infections [1-3]. More recently, these statistics have

\footnotetext{
* Correspondence: pinkesm@upstate.edu

${ }^{1}$ College of Medicine, SUNY Upstate Medical University, 766 Irving Avenue,

Syracuse, NY 13210, USA

Full list of author information is available at the end of the article
}

approached approximately $97 \%$ (E. faecalis) and 1-2\% (E. faecium), with about $1 \%$ of the remaining enterococcal infections originating from other enterococcal species [4]. E. hirae is rarely identified in humans and may be a commensal pathogen in psittacine birds [5]. It has also been associated with poultry and suckling animals $[5,6]$. Data on the prevalence of $E$. hirae infections in humans is limited, but $E$. hirae may account for between 0.4 and $3.03 \%$ of all enterococcal infections and may be underdiagnosed due to rarity $[2,3]$. To our knowledge, this case constitutes the fifth known case of $E$. hirae endocarditis. We review the clinical aspects of the previous four known cases of $E$. hirae endocarditis. 


\section{Case presentation}

A 64-year-old Caucasian female was transferred to a tertiary care hospital with a fever, hypotension, and a two-week history of lightheadedness and dizziness with near-syncopal episodes and mild visual disturbances. She reported a weight loss of 40 pounds over the past 2 years due to progressive dysphagia, and upper endoscopy at the previous hospital revealed esophageal candidiasis. Her previous medical history included COPD, asthma, recurring right lower extremity DVT, achalasia, atrial fibrillation (on warfarin), fibromyalgia, hypertension, hypothyroidism, cholecystectomy, and a distant history of Hodgkin's lymphoma (for which she received chemotherapy). BMI was $30.62 \mathrm{~kg} / \mathrm{m}^{2}$. She denied chest pain and shortness of breath. Upon arrival at the hospital, she was found to be in atrial fibrillation with rapid ventricular response and complained of palpitations. Physical exam was notable for expiratory wheezes and a $2 / 6$ systolic ejection murmur at the right sternal border. She spontaneously converted to sinus rhythm after receiving intravenous metoprolol, and her EKG showed T-wave inversion in the inferior leads. Her labs showed a white blood cell count of $8.0 \times 10^{3} / \mathrm{mm}^{3}$, an INR of 5.7 , a hematocrit of $25.6 \%$, a troponin I level of $0.05 \mathrm{ng} / \mathrm{mL}$, and a BNP of $6696 \mathrm{pg} / \mathrm{mL}$. Stool guaiacs were positive. A chest $\mathrm{x}$-ray and $\mathrm{CT}$ of the abdomen and pelvis were negative for acute disease. A 2D echocardiogram revealed severe aortic stenosis with a peak gradient of $91 \mathrm{mmHg}$, a mean gradient of $61 \mathrm{mmHg}$, and normal systolic left ventricular function (see Figs. 1 and 2). She was given two units of packed red blood cells, four units of fresh frozen plasma, and fluconazole.

Four days after initial presentation, the patient underwent right and left heart catheterization for evaluation of her coronary arteries and aortic valve. She was found to have severe aortic stenosis (mean gradient of $56 \mathrm{mmHg}$, valve area of $0.64 \mathrm{~cm}^{2}$ ), mild pulmonary hypertension $(28 \mathrm{mmHg})$, and normal left systolic function, with no evidence of significant coronary artery disease. The aortic root size was noted to be normal. Valve surgery was recommended.

The patient underwent minimally invasive aortic valve replacement with a bovine pericardial valve, cryoablation of both atria, and clipping of the left atrial appendage. The aortic valve was found to have a bicuspid, thickened appearance with calcifications, multiple small vegetations, and a root abscess beneath the right coronary cusp. With a new suspicion of infective endocarditis, the patient was placed on broad-spectrum intravenous antibiotics with vancomycin and piperacillin/tazobactam. Two intraoperative peripheral blood cultures were taken, and an infectious disease consult was requested.

One day post-surgery, the level of C-reactive protein was measured at $8.4 \mathrm{mg} / \mathrm{L}$, and the sedimentation rate was $46 \mathrm{~mm} / \mathrm{hr}$. Three days post-surgery, a tissue culture from the aortic valve vegetations identified Enterococcus hirae through MALDI-TOF. The tissue sample was sensitive to ampicillin, amoxicillin, and vancomycin, and it demonstrated synergy with gentamicin and streptomycin. Antibiotic treatment was then switched to intravenous ampicillin and ceftriaxone; the patient declined aminoglycoside treatment due to concerns of nephrotoxicity. Both blood cultures were negative for bacterial growth. The patient denied any exposure to psittacine birds, poultry, and suckling animals, as well as recent travel.

The patient had an uncomplicated postoperative course. She was discharged with the goal of 6 weeks of treatment with intravenous ampicillin and ceftriaxone.

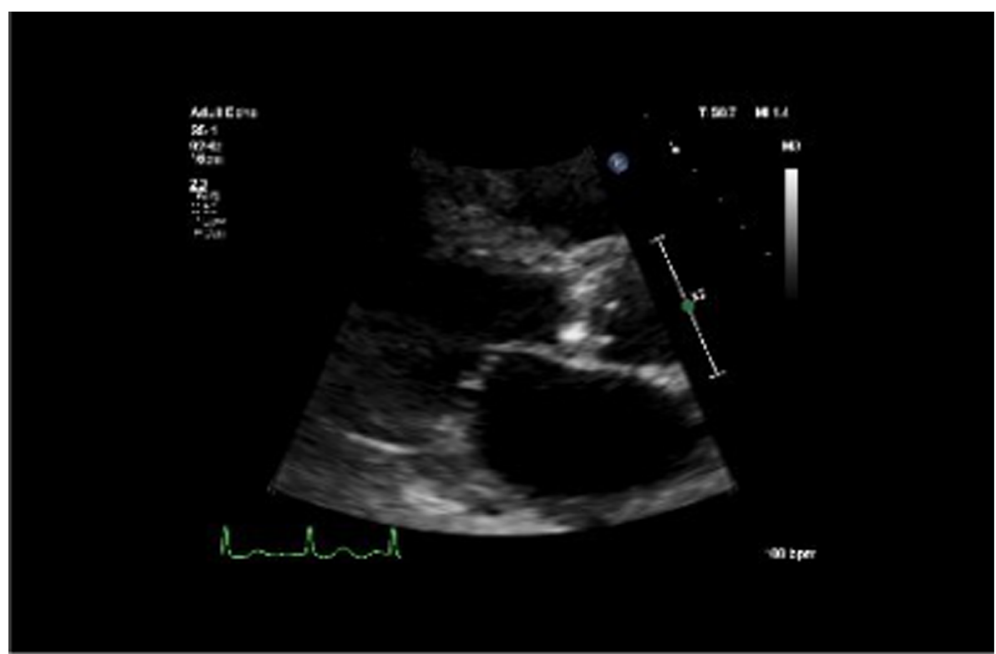

Fig. 1 Parasternal long-axis view on 2D transthoracic echocardiogram upon patient's initial presentation, demonstrating normal left ventricular systolic function and severe aortic stenosis with no indications of vegetations or infectious processes 


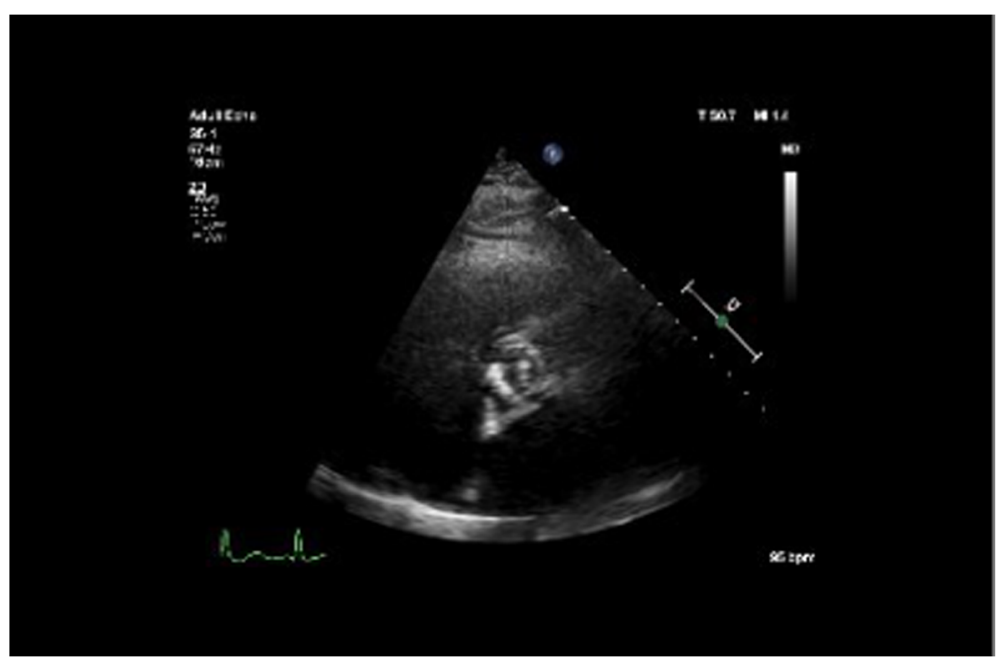

Fig. 2 Parasternal short-axis view from the same echocardiogram

Two months after her discharge, two peripheral blood cultures were negative for bacterial growth. Ten months after her discharge, the patient presented for multifocal pneumonia, and blood cultures were found to be negative then as well. Fifteen months after her initial presentation, the patient had a follow-up appointment with Cardiology. Mild mitral and mild tricuspid regurgitation were noted, and a $1 / 6$ systolic murmur was appreciated at the right upper sternal border. A comprehensive 2D transthoracic Doppler echocardiogram at the time showed a well seated aortic bioprosthetic valve with normal-sized aortic root and without evidence of dehiscence, paravalvular leak, or aortic stenosis.

\section{Discussion and conclusions}

Though enterococci are estimated to cause $5-15 \%$ of bacterial endocarditis, enterococcal endocarditis is a relatively uncommon sequela of enterococcal bacteremia [1]. Between $0.5-8 \%$ of patients with enterococcal bacteremia may be diagnosed with enterococcal endocarditis [1, 3, 7]. Risk factors for enterococcal bacteremia and endocarditis have been identified as increased age, male gender, underlying cardiac pathology, and a genitourinary or biliary source $[1,3,4,7]$. Other factors common to enterococcal endocarditis include aortic or mitral valve involvement and a subacute presentation [1, 7]. In those who abuse drugs, right-sided enterococcal endocarditis appears to be rare; mitral and aortic valve enterococcal involvement remain more common in this population [7].

The five known cases of $E$. hirae endocarditis, as summarized in Table 1, occurred in a 72-year-old male [8], 78-year-old female [9], 56-year-old male [10], 70-yearold male [11], and 64-year-old female. All five cases involved the aortic valve, with one case that involved both the aortic and mitral valves [10]. Additionally, there were underlying risk factors for cardiac pathology in each of the first three cases, as well as in ours: a history of coronary artery disease and percutaneous transluminal coronary angioplasty [8]; prior aortic valve replacement with a bioprosthetic valve [9]; cardiac arrhythmia with prior surgical ablation, and a patent foramen ovale [10]; and a bicuspid aortic valve, respectively. The past medical history for the fourth case was not reported, although it was noted that this patient had lived in Vietnam for 2 years, with recent travel throughout Southeast Asia [11].

All five cases involved a history of at least 1 month of subacute symptoms, typically fever, weight loss, fatigue, and weakness [8-11]. The fourth case presented with 3 months of bilateral lower extremity edema, exertional dyspnea, and fatigue [11]. Two patients presented acutely, and both acute presentations did not at first appear to be infective endocarditis. One case presented acutely with dysarthria, left hemiparesis, and a brain lesion on MRI [10]. Our case presented with hypotension and atrial fibrillation with rapid ventricular response, in the context of a history of 2 weeks of lightheadedness, dizziness, near-syncopal episodes, and mild visual disturbances.

None of the five cases involved a documented source of entry, including a genitourinary or biliary source, though some patients had distant histories of gastric surgery. Our case had positive stool guaiacs and a remote history of cholecystectomy. Only one case was theorized to have a probable source, in which the patient had had multiple colonic polyps removed and was later found, post-relapse and after a second colonoscopy, to have a non-neoplastic adenoma in a removed polyp [9]. Another patient had a history of gastric leiomyoma removal [10].

Previous cases have discussed the need for definitive genetic species identification of $E$. hirae. In the first two 
Table 1 Clinical characteristics of patients with endocarditis caused by Enterococcus hirae

\begin{tabular}{|c|c|c|c|c|c|}
\hline Patient & 1 & 2 & 3 & 4 & 5 \\
\hline Age, y & 72 & 78 & 56 & 70 & 64 \\
\hline Sex & M & $\mathrm{F}$ & M & M & $\mathrm{F}$ \\
\hline $\begin{array}{l}\text { Valve } \\
\text { involvement }\end{array}$ & Aortic insufficiency. & $\begin{array}{l}\text { Vegetation on aortic } \\
\text { prosthetic valve present } \\
\text { during relapse; normal TTE/ } \\
\text { TEE upon initial } \\
\text { presentation. }\end{array}$ & $\begin{array}{l}\text { Aortic and mitral valve } \\
\text { reflux. }\end{array}$ & $\begin{array}{l}\text { Severe aortic regurgitation } \\
\text { with prolapse, fusion, small } \\
\text { echodensity, and } \\
\text { perforation of aortic cusps. }\end{array}$ & $\begin{array}{l}\text { Bicuspid aortic valve } \\
\text { with stenosis, root } \\
\text { abscess, } \\
\text { calcifications; no } \\
\text { evidence of } \\
\text { vegetations or } \\
\text { abscess on TTE. }\end{array}$ \\
\hline $\begin{array}{l}\text { Medical } \\
\text { history }\end{array}$ & $\begin{array}{l}\text { Coronary artery disease, } \\
\text { percutaneous transluminal } \\
\text { coronary angioplasty. }\end{array}$ & $\begin{array}{l}\text { Diabetes mellitus, } \\
\text { hypertension, prior aortic } \\
\text { valve replacement with } \\
\text { bioprosthetic. }\end{array}$ & $\begin{array}{l}\text { Hypertension, diabetes } \\
\text { mellitus, cardiac } \\
\text { arrhythmia with prior } \\
\text { surgical ablation, } \\
\text { surgical removal of } \\
\text { gastric leiomyoma. }\end{array}$ & Unknown. & $\begin{array}{l}\text { Hodgkin's } \\
\text { lymphoma, asthma, } \\
\text { achalasia, recurrent } \\
\text { right lower } \\
\text { extremity DVT, } \\
\text { fibromyalgia, } \\
\text { cholecystectomy. }\end{array}$ \\
\hline Identification s & $\operatorname{sod}_{\text {int }}$ gene sequencing. & $\begin{array}{l}16 \mathrm{~S} r N A \text {, sod } A_{\text {int }} \text { gene } \\
\text { sequencing. }\end{array}$ & Unknown. & MALDI-TOF. & MALDI-TOF. \\
\hline Treatment & $\begin{array}{l}\text { Aortic valve replacement. } \\
\text { Ampicillin and gentamicin } \\
\text { ( } 4 \text { weeks), with rifampin } \\
\text { added (15 days); total } 4 \\
\text { weeks. }\end{array}$ & $\begin{array}{l}\text { Amoxicillin and gentamicin } \\
\text { ( } 2 \text { weeks), followed by } \\
\text { amoxicillin and rifampin ( } 4 \\
\text { weeks); total } 6 \text { weeks. }\end{array}$ & $\begin{array}{l}\text { Aortic valve } \\
\text { replacement. } \\
\text { Ampicillin and } \\
\text { gentamicin ( } 4 \text { weeks), } \\
\text { followed by amoxicillin } \\
\text { and rifampin ( } 2 \text { weeks); } \\
\text { total } 6 \text { weeks. }\end{array}$ & $\begin{array}{l}\text { Aortic valve replacement. } \\
\text { Ampicillin and ceftriaxone, } \\
\text { followed by IV penicillin G } \\
\text { and ceftriaxone for } 6 \text { weeks, } \\
\text { with indefinite chronic } \\
\text { suppressive therapy of oral } \\
\text { penicillin. }\end{array}$ & $\begin{array}{l}\text { Aortic valve } \\
\text { replacement. } \\
\text { Ampicillin and } \\
\text { ceftriaxone (6 } \\
\text { weeks). }\end{array}$ \\
\hline Relapse & $\begin{array}{l}\text { Yes, } 3 \text { months after } \\
\text { antibiotic discontinuation. } \\
\text { Treated with aortic valve } \\
\text { replacement and } \\
\text { vancomycin/gentamicin ( } 6 \\
\text { weeks) followed by } \\
\text { amoxicillin ( } 2 \text { weeks) for a } \\
\text { total of } 8 \text { weeks of } \\
\text { antibiotic therapy. } \\
\text { Resolved. }\end{array}$ & $\begin{array}{l}\text { Yes, } 4 \text { months after } \\
\text { antibiotic discontinuation. } \\
\text { Treated with the same } \\
\text { regimen as before. Surgery } \\
\text { contraindicated by poor } \\
\text { patient condition. Resolved. }\end{array}$ & No. & No. & No. \\
\hline Notes & Subacute presentation. & $\begin{array}{l}\text { Subacute presentation. No } \\
\text { evidence of endocarditis on } \\
\text { initial TTE/TEE. Multiple } \\
\text { colonic polyps removed. } \\
\text { Post-relapse, colonic polyp } \\
\text { with non-neoplastic aden- } \\
\text { oma removed. The only } \\
\text { case of the five not to re- } \\
\text { quire aortic valve replace- } \\
\text { ment, although the } \\
\text { infected valve was already a } \\
\text { prosthetic valve. }\end{array}$ & $\begin{array}{l}\text { Presented acutely as } \\
\text { neurological deficit } \\
\text { with slurred speech } \\
\text { and left hemiparesis. }\end{array}$ & $\begin{array}{l}\text { Subacute presentation with } \\
3 \text { months of bilateral lower } \\
\text { extremity edema, exertional } \\
\text { dyspnea, and fatigue; } 1 \text { year } \\
\text { of fevers and mild weight } \\
\text { loss. Lived in Vietnam for } 2 \\
\text { years, with travel } \\
\text { throughout Southeast Asia. }\end{array}$ & $\begin{array}{l}\text { Presented acutely as } \\
\text { hypotension and } \\
\text { atrial fibrillation with } \\
\text { rapid ventricular } \\
\text { response. }\end{array}$ \\
\hline $\begin{array}{l}\text { Year of } \\
\text { publication, } \\
\text { reference }\end{array}$ & $2002[8]$ & 2011 [9] & 2013 [10] & 2019 [11] & 2019 \\
\hline
\end{tabular}

All reported cases of $E$. hirae endocarditis have involved the aortic valve. Presentations of $E$. hirae endocarditis have been both acute and subacute. Treatment requires several weeks of bactericidal treatment, classically ampicillin and gentamicin in combination, and often necessitates aortic valve replacement TTE Transthoracic echocardiography, TEE Transesophageal echocardiography

cases, the API 20 Strep, rapid ID 32 Strep, and IDGP N052 card systems could not accurately identify $E$. hirae, and definitive identification with $\operatorname{sod} A_{\text {int }}$ and/or $16 \mathrm{~S}$ rRNA gene sequencing was required $[8,9]$. There has also been an example of Lactococcus garvieae that was misidentified by the Vitek2 $2^{\circ}$ automated system (bioMérieux, Marcy l'Étoile,
France) as E. hirae [12]. The fourth case was identified using MALDI-TOF [11], as was ours.

All five cases responded to antibiotic treatment, and all five patients survived. The first three cases were treated with ampicillin or amoxicillin, plus gentamicin, followed by rifampin. Four of the five cases, including 
ours, resulted in aortic valve replacement $[8,10]$. In the only case that did not require a valve replacement, the infected aortic valve was already a prosthetic valve, and the patient's poor condition contraindicated surgery [9]. Two patients relapsed several months following antibiotic discontinuation $[8,9]$. The first of the two relapses resolved after treatment with vancomycin, gentamicin, and amoxicillin, as well as aortic valve replacement [8]. The second relapse, in which the patient already had a prosthetic aortic valve, resolved after repetition of the initial treatment, amoxicillin, gentamicin and rifampin [9]. The fourth case was treated with ampicillin and ceftriaxone, following treatment guideline changes [4], and the patient was discharged on 6 weeks of IV penicillin G and ceftriaxone, followed by indefinite chronic suppressive therapy with oral penicillin [11]. Our case was treated with 6 weeks of ampicillin and ceftriaxone, with no evidence of relapse at 15 months after the patient's discharge.

Bactericidal antibacterial activity against enterococci has classically required the combination of a $\beta$-lactam antibiotic, such as ampicillin, with an aminoglycoside, such as gentamicin. In the population typically affected by enterococcal endocarditis, however, patients tend to be older, to have multiple comorbid conditions, and to have poorer renal function at baseline. For these patients, therefore, the risks of aminoglycoside-associated nephrotoxicity leading to renal failure are increased in a treatment course of several weeks, and may outweigh the benefits of aminoglycoside use [4].

Our case reinforces previous findings that $E$. hirae endocarditis may be successfully treated with ampicillin and ceftriaxone, which may allow patients to avoid the significant toxicities of gentamicin.

\section{Acknowledgments}

Special thanks to Katherine Everett, FNP-C and Ziad El-Khally, MD FACC for their assistance in acquiring the echocardiogram images.

\footnotetext{
Authors' contributions

MEP drafted and prepared the manuscript. CW analyzed and interpreted the patient data and edited the manuscript. CSW acquired, analyzed, and interpreted the patient data and edited the manuscript. All authors read and approved the final manuscript.
}

\section{Funding}

There were no sources of funding used in the conception, composition, editing, or submission of this manuscript.

\section{Availability of data and materials}

Data sharing is not applicable to this article as no datasets were generated or analyzed during the current study.

\section{Ethics approval and consent to participate}

Not applicable.

\section{Consent for publication}

The patient's written and signed consent for this case report to be published was obtained prior to the drafting of the manuscript and may be made available upon request.

\section{Competing interests}

The authors declare that they have no competing interests.

\section{Author details}

${ }^{1}$ College of Medicine, SUNY Upstate Medical University, 766 Irving Avenue, Syracuse, NY 13210, USA. ${ }^{2}$ Department of Medicine, SUNY Upstate Medical University, University Hospital, 750 E. Adams Street, Syracuse, NY 13210, USA. ${ }^{3}$ Department of Infectious Disease, St. Joseph's Health Center, 301 Prospect Avenue, Syracuse, NY 13203, USA.

Received: 6 August 2019 Accepted: 1 October 2019

Published online: 24 October 2019

\section{References}

1. Murray BE. The life and times of the Enterococcus. Clin Microbiol Rev. 1990; 3(1):46-65.

2. Anbumani N, Kalyani J, Mallika M. Isolation, distribution and prevalence of various species of enterococci isolated from clinical specimens in a tertiary care hospital. Indian J Pathol Microbiol. 2005;48(4):534-7.

3. Tan C-K, Lai C-C, Wang J-Y, Lin S-H, Liao C-H, Huang Y-T, et al. Bacteremia caused by non-faecalis and non-faecium enterococcus species at a medical center in Taiwan, 2000 to 2008. J Inf Secur. 2010;61:34-43. https://doi.org/ 10.1016/j.jinf.2010.04.007.

4. Baddour LM, Wilson WR, Bayer AS, Fowler VG, Tleyjeh IM, Rybak MJ, et al. Infective endocarditis in adults: diagnosis, antimicrobial therapy, and management of complications. Circulation. 2015;132:1435-86. https://doi. org/10.1161/CIR.0000000000000296.

5. Devriese LA, Chiers K, de Herdt P, Vanrompay D, Desmidt M, Ducatelle R, et al. Enterococcus hirae infections in psittacine birds: epidemiological, pathological and bacteriological observations. Avian Pathol. 1995;24(3):52331. https://doi.org/10.1080/03079459508419091.

6. Devriese LA, Haesebrouck F. Enterococcus hirae in different animal species. Vet Rec. 1991;129(17):391-2.

7. Guerrero ML, Goyenechea A, Verdejo C, Roblas RF, de Górgolas M. Enterococcal endocarditis on native and prosthetic valves: a revew of clinical and prognostic factors with emphasis on hospital-acquired infections as a major determinant of outcome. Medicine. 2007;86(6):363-77. https://doi.org/10.1097/MD.0b013e31815d5386.

8. Poyart C, Lambert T, Morand P, Abassade P, Quesne G, Baudouy Y, et al. Native valve endocarditis due to Enterococcus hirae. J Clin Microbiol. 2002; 40(7):2689-90. https://doi.org/10.1128/JCM.40.7.2689-2690.2002.

9. Talarmin JP, Pineau S, Guillouzouic A, Boutoille D, Giraudeau C, Reynaud A, et al. Relapse of Enterococcus hirae prosthetic valve endocarditis. J Clin Microbiol. 2011;49(3):1182-4. https://doi.org/10.1128/JCM.02049-10.

10. Anghinah R, Watanabe RG, Simabukuro MM, Guariglia C, Pinto LF, de Menezes e Gonçalves DC. Native valve endocarditis due to Enterococcus hirae presenting as a neurological deficit. Case Rep Neurol Med. 2013;2013: 636070. https://doi.org/10.1155/2013/636070.

11. Ebeling CG, Romito BT. Aortic valve endocarditis from Enterococcus hirae infection. Proc (Bayl Univ Med Cent). 2019;32(2):249-50. https://doi.org/10. 1080/08998280.2018.1551698.

12. Vinh DC, Nichol KA, Rand F, Embil JM. Native-valve bacterial endocarditis caused by Lactococcus garvieae. Diagn Microbiol Infect Dis. 2006;56:91-4. https://doi.org/10.1016/j.diagmicrobio.2006.02.010.

\section{Publisher's Note}

Springer Nature remains neutral with regard to jurisdictional claims in published maps and institutional affiliations. 